\title{
Comparison of the Effects of Paricalcitol and Calcitriol on Vascular Calcification in Patients Undergoing Chronic Hemodialysis
}

\author{
Kronik Hemodiyaliz Hastalarında Parikalsitol ve Kalsitriolün Vasküler Kalsifikasyon \\ Üzerine Etkilerinin Karşılaştırılması
}

(D) Süleyman Karaköse ${ }^{1}$, (D) Zeynep Bal2, (D) Siren Sezer²

1University of Health Sciences Turkey, Konya Training and Research Hospital, Clinic of Nephrology, Konya, Turkey

2Bașkent University Faculty of Medicine, Department of Nephrology, Ankara, Turkey

\begin{abstract}
Introduction: Secondary hyperparathyroidism is considered an unconventional risk factor of vascular calcification in hemodialysis patients (HPs). An important factor of vascular calcification is vitamin D receptor activator used in the treatment of secondary hyperparathyroidism. This study aimed to investigate the change in pulse wave velocity (PWV) and fibroblast growth factor-23 (FGF-23), Klotho, and 25-hydroxyvitamin D [25(OH)D] levels as a result of 1-year treatment with paricalcitol or calcitriol among patients undergoing chronic dialysis.
\end{abstract}

Methods: Eighty HPs were included in the study, and PWV measurements were obtained at the beginning and after 1 year of treatment. Serum Klotho and 25(OH)D levels were evaluated at the end of 1-year treatment with paricalcitol or calcitriol.

Results: At the end of 1 year, FGF-23 levels in the paricalcitol group were significantly lower than those in the calcitriol group. Klotho and $25(\mathrm{OH}) \mathrm{D}$ levels were significantly higher in the paricalcitol group. The PWV at the beginning of the study was statistically similar between the two groups; in contrast, PWV at 1 year was significantly lower in the paricalcitol group than in the calcitriol group $(p=0.002)$. When the PWV change was considered as the dependent variable, the most powerful determinant in multiple regression analysis was the FGF-23 level.

Conclusion: In HPs, paricalcitol has a protective effect against vascular calcification compared with calcitriol treatment, owing to its positive effects on both parathyroid hormone and calcium-phosphorus balance. Therefore, paricalcitol should be the first choice in the treatment of secondary hyperparathyroidism.

Keywords: Paricalcitol, calcitriol, vascular calcification, pulse wave velocity, FGF-23 öz

Amaç: Sekonder hiperparatiroidizm, hemodiyaliz hastalarında $(\mathrm{HH})$ vasküler kalsifikasyon gelișiminde geleneksel olmayan bir risk faktörü olarak kabul edilir. Vasküler kalsifikasyon üzerinde etkili olan önemli bir faktör, sekonder hiperparatiroidizmin tedavisinde kullanılan D vitamini reseptör aktivatörleridir. Bu çalışmada, kronik diyaliz hastalarında 1 yıllık parikalsitol veya kalsitriol tedavileri sonucunda nabız dalga hızındaki (NDH) değişimi ve fibroblast büyüme faktörü-23 (FGF-23), Klotho ve 25 hidroksivitamini D [25(OH)D] düzeylerini araștırmayı amaçladık.

Yöntemler: Seksen HH çalışmaya dahil edildi ve tedavinin başlangıcında ve bir yıl sonra PWV ölçümleri yapıldı. Parikalsitol veya kalsitriol ile bir yıllık tedavinin sonunda serum FGF-23, Klotho ve 25(OH)D düzeyleri değerlendirildi.

Bulgular: Parikalsitol grubundaki FGF-23 düzeyleri, bir yıl sonunda kalsitriol grubuna göre istatistiksel olarak anlamlı derecede düşüktü; Klotho ve $25(\mathrm{OH}) \mathrm{D}$ düzeyleri istatistiksel olarak anlamlı derecede yüksek bulundu. Çalıșmanın başındaki NDH iki grup arasında istatistiksel olarak benzerdi; bir yılın sonundaki NDH değeri parikalsitol grubunda kalsitriol grubuna göre istatistiksel olarak anlamlı derecede yavaştı $(p=0,002)$. NDH değișimi bağımlı değişken olarak alındığında çoklu regresyon analizinde en güçlü belirleyicinin FGF-23 düzeyleri olduğu bulundu.

Sonuç: HH'lerde kullanılan parikalsitol tedavisi, hem paratiroid hormonu hem de kalsiyum-fosfor dengesi üzerindeki olumlu etkileri nedeniyle kalsitriol tedavisine göre vasküler kalsifikasyondan koruyucu etkileri vardır. Bu nedenle, sekonder hiperparatiroidi tedavisinde parikalsitol ilk tercih olmalıdır.

Anahtar Kelimeler: Parikalsitol, kalsitriol, vasküler kalsifikasyon, nabız dalga hızı, FGF-23 


\section{Introduction}

The most important cause of cardiovascular mortality in both the general population and hemodialysis patients (HPS) is calcification occurring in the vessels. Uremia-related factors might play an important role in the development of vascular calcification in HPs. Secondary hyperparathyroidism is considered an unconventional risk factor of vascular calcification and is associated with increased mortality for patients in the predialysis stage and undergoing maintenance hemodialysis (MHD) (1).

All processes in the development of vascular calcification mainly involve systemic/local activator and inhibitory factors. In addition to parathyroid hormone (PTH) and 1,25-dihydroxyvitamin D [1,25(OH)2D3], which play a role in phosphorus metabolism, fibroblast growth factor-23 (FGF-23) and Klotho have been identified as two important factors. These two factors, which plays an important role in phosphorus and vitamin D regulation, have been shown to be associated with vascular calcification including atherosclerosis and soft tissue calcification $(2,3)$. Currently, pulse wave velocity (PWV) measurement is a simple, non-invasive, reliable, and reproducible method for measuring arterial stiffness. PWV is associated with increased mortality in populations with and without kidney disease (4). In addition, PWV has been associated with total calcification scores as measured using electron-beam computed tomography (5).

An important factor affecting vascular calcification is vitamin $D$ receptor activators used in the treatment of secondary hyperparathyroidism in HPs. In this study, we aimed to investigate the change in PWV as well as FGF-23, Klotho, and 25-hydroxyvitamin D [25(OH)D] levels following 1-year treatment with paricalcitol or calcitriol among patients undergoing chronic dialysis.

\section{Methods}

This single-center randomized study was conducted at a university teaching hospital. After approval of the study protocol by Başkent University Faculty of Medicine Local Ethics Committee (approval number: KA12/83, date: 12.05.2012), 300 patients undergoing MHD were evaluated, of which 80 met the inclusion criteria. Written informed consent was obtained from all participants. The inclusion criteria was as follows: Patients receiving dialysis treatment for chronic renal failure since at least 1 year, for 4 hours 3 times per week at our hemodialysis unit and those with PTH levels 300-1000 pg/mL, corrected Ca level of 8.5-9.5 $\mathrm{mg} / \mathrm{dL}$, phosphorus level $\leq 5.5 \mathrm{mg} / \mathrm{dL}$, calcium-phosphorus product (CaxP) $<55$, and albumin $\geq 3 \mathrm{~g} / \mathrm{dL}$. The exclusion criteria were as follows: $\mathrm{Kt} / \mathrm{V}$ $<1.4$, chronic inflammatory disease, malignancy, chronic liver disease, a change in vitamin $\mathrm{D}$ receptor activator treatment during follow-up, receiving calcimimetic therapy or addition of this therapy during followup, hospitalization during follow-up, a diagnosis of peripheral arterial disease or patients who underwent stenting/operation for this diagnosis, allergy to paricalcitol or calcitriol, pregnancy or breastfeeding, history of parathyroidectomy, mean hemoglobin $<10.5 \mathrm{~g} / \mathrm{dL}$, doxercalciferol treatment or unresponsiveness to erythropoietin treatment, severe cardiac arrhythmia, uncontrolled hypertension, and use of warfarin.

The demographic data were extract from patient files, and the results of tests that were performed monthly (phosphorus, calcium, albumin, sodium, potassium alanine aminotransferase, and complete blood count) and every 3 months [PTH and alkaline phosphatase (ALP)] were extracted for a year. Data on phosphorus binders (calcium acetate and/or sevelamer by calculating the amount of contained elemental calcium) and vitamin D receptor activators (paricalcitol or calcitriol) that were used monthly, were recorded for 1 year.

At the end of the first year, blood samples were obtained from all patients to evaluate FGF-23, Klotho, and 25(OH)D levels and were stored at $-80{ }^{\circ} \mathrm{C}$. Serum FGF-23 and Klotho levels were measured using enzyme-linked immunosorbent assay using Uscn Life Science Inc. kits (Wuhan, P.R. China). The reference range for FGF-23 was 15.6-1000 pg/ $\mathrm{mL}$. Intra and inter-assay variations were $<10 \%$ and $<12 \%$, respectively. The reference range for Klotho was $0.156-10 \mathrm{ng} / \mathrm{mL}$, and the intra and inter-assay variations were $<10 \%$ and $<12 \%$, respectively.

PWV was measured at the beginning of the study and at the first year. A SphygmoCor (AtCor Medical Instruments) tonometry device was used for PWV measurements using the method reported by Kelly et al. (6).

\section{Statistical Analysis}

The data were analyzed using the SPSS for Windows 21.0 program, and study results are reported as means \pm standard deviations and percentages. Between the two groups, Student's t-test was used for comparing quantitative variables when the data were normally distributed, and Mann-Whitney $U$ test was used for non-parametric cases. Group comparisons for categorical variables were analyzed using crosstab statistics, for which the chi-square test was used. The Fisher's exact test was used for $2 \times 2$ tables that did not meet the required condition. Kruskal-Wallis variance analysis was used for more than two independent group comparisons for quantitative variables, and the Mann-Whitney $U$ test was used for subgroup comparisons. Bonferroni correction was applied to the alpha significance level, and $p<0.017$ was considered statistically significant for these comparisons. Relationships among quantitative variables were evaluated using Spearman's correlation analysis. The statistical significance level was accepted at $\mathrm{p}<0.05$.

\section{Results}

Eighty patients undergoing MHD were included in the study and were categorized into two groups according to the vitamin D treatment they received: paricalcitol ( $n=40$; mean age: $51.6 \pm 12.6$ years; female/male: 14/26) and calcitriol groups ( $n=40$; mean age: $53.9 \pm 16.8$ years; female/ male: 16/24). Age, sex, hemodialysis duration, etiologies of chronic kidney disease, and Charlson Comorbidity Index values were statistically similar in both the groups ( $p>0.05$ for all). The descriptive characteristics of all enrolled patients are shown in Table 1.

Patients were followed up for 1 year without any changes in vitamin D treatment. Results revealed no differences between baseline PTH, calcium, phosphorus, CaxP, and ALP values in both the groups ( $p>0.05$ for all). The increase in PTH from baseline to 1 year was not significant in the paricalcitol group (from $573.4 \pm 180.7 \mathrm{pg} / \mathrm{mL}$ to $598.5 \pm 191.3$ $\mathrm{pg} / \mathrm{mL} ; \mathrm{p}=0.461)$. In the calcitriol group, the increase in PTH from baseline $(515.2 \pm 176.6 \mathrm{pg} / \mathrm{mL})$ to 1 year $(681.9 \pm 371.4 \mathrm{pg} / \mathrm{mL} ; \mathrm{p}=0.002)$ 
was statistically significant. In addition, calcium values were similar in both the groups; however, phosphorus and CaxP values were lower in the paricalcitol group than in the calcitriol group at every 3-month assessment ( $p<0.05$ for all) (Table 2$)$. There was no statistically significant difference between ALP values in both the groups $(p>0.05)$ (Table 2).

\section{Table 1. Demographic characteristics of patients}

\begin{tabular}{|c|c|c|c|}
\hline Mean \pm SD, median (IR) & Paricalcitol group $(n=40)$ & Calcitriol group $(n=40)$ & $p$-value \\
\hline Age (years) & $51.6 \pm 12.6$ & $53.9 \pm 16.8$ & 0.492 \\
\hline Sex (female, \%) & $14(35)$ & $16(40)$ & 0.644 \\
\hline Hemodialysis duration (years) & $11(4-12)$ & $6(6-9)$ & 0.626 \\
\hline \multicolumn{4}{|l|}{ Etiology of CKD (n, \%) } \\
\hline DM & $7(17.5)$ & $10(25)$ & \multirow{6}{*}{0.881} \\
\hline HT & $9(22.5)$ & $11(2.5)$ & \\
\hline GN & $4(10)$ & $3(7.5)$ & \\
\hline ADPKD & $4(10)$ & $2(5)$ & \\
\hline Other & $10(25)$ & $8(20)$ & \\
\hline Unknown & $6(15)$ & $6(15)$ & \\
\hline CCl (score) & $5.2 \pm 2.4$ & $4.9 \pm 2.9$ & 0.648 \\
\hline
\end{tabular}

CKD: Chronic kidney disease, DM: diabetes mellitus, GN: glomerulonephritis, HT: hypertension, ADPKD: autosomal dominant polycystic kidney disease, CCI: Charlson Comorbidity Index, IR: interquartile range, SD: Standard deviation

\section{Table 2. One-year parathyroid hormone, calcium, phosphorus, calcium-phosphorus product, and alkaline phosphatase levels in both groups}

\begin{tabular}{|c|c|c|c|}
\hline Mean \pm SD, median (IR) & Paricalcitol group $(n=40)$ & Calcitriol group $(n=40)$ & $p$-value \\
\hline Basal PTH (pg/mL) & $573.4 \pm 180.7$ & $515.2 \pm 176.6$ & 0.148 \\
\hline PTH at $4^{\text {th }}$ month $(p g / m L)$ & $577.5 \pm 247.1$ & $484.3 \pm 290.3$ & 0.126 \\
\hline PTH at $7^{\text {th }}$ month $(\mathrm{pg} / \mathrm{mL})$ & $591.7 \pm 240.7$ & $581.4 \pm 293.4$ & 0.863 \\
\hline PTH at $10^{\text {th }}$ month $(\mathrm{pg} / \mathrm{mL})$ & $595.1 \pm 247.0$ & $632.5 \pm 293.1$ & 0.640 \\
\hline PTH at $13^{\text {th }}$ month $(\mathrm{pg} / \mathrm{mL})$ & $598.5 \pm 191.3$ & $681.9 \pm 371.4$ & 0.210 \\
\hline$\%$ PTH change & $+10.3 \%$ & $+35.0 \%$ & 0.085 \\
\hline Basal Ca (mg/dL) & $8.6 \pm 0.7$ & $8.4 \pm 0.7$ & 0.261 \\
\hline Basal P (mg/dL) & $5.1 \pm 0.9$ & $5.4 \pm 1.2$ & 0.163 \\
\hline Basal CaxP & $44.3 \pm 8.3$ & $46.1 \pm 10.2$ & 0.383 \\
\hline Ca at $1^{\text {st }}-3^{\text {rd }}$ month $(\mathrm{mg} / \mathrm{dL})$ & $8.7 \pm 0.6$ & $8.6 \pm 0.6$ & 0.248 \\
\hline$P$ at $1^{\text {st }}-3^{\text {rd }}$ month $(\mathrm{mg} / \mathrm{dL})$ & $5.1 \pm 0.8$ & $5.9 \pm 0.9$ & 0.001 \\
\hline CaxP at $1^{\text {st }}-3^{\text {rd }}$ month & $44.8 \pm 8.3$ & $50.6 \pm 8.4$ & 0.003 \\
\hline $\mathrm{Ca}$ at $4-6^{\text {th }}$ month $(\mathrm{mg} / \mathrm{dL})$ & $8.5 \pm 0.7$ & $8.8 \pm 0.5$ & 0.039 \\
\hline$P$ at $4-6^{\text {th }}$ month $(\mathrm{mg} / \mathrm{dL})$ & $5.4 \pm 1.1$ & $5.9 \pm 1.1$ & 0.068 \\
\hline CaxP at $4-6^{\text {th }}$ month & $46.6 \pm 10.2$ & $52.3 \pm 10.4$ & 0.016 \\
\hline $\mathrm{Ca}$ at $7-9^{\text {th }}$ month $(\mathrm{mg} / \mathrm{dL})$ & $8.6 \pm 0.7$ & $8.9 \pm 0.4$ & 0.052 \\
\hline $\mathrm{P}$ at $7-9^{\text {th }}$ month $(\mathrm{mg} / \mathrm{dL})$ & $5.4 \pm 1.1$ & $6.0 \pm 1.1$ & 0.004 \\
\hline CaxP at $7-9^{\text {th }}$ month & $46.8 \pm 10.9$ & $54.6 \pm 10.9$ & 0.002 \\
\hline Ca at $9-12^{\text {th }}$ month $(\mathrm{mg} / \mathrm{dL})$ & $8.6 \pm 0.6$ & $8.8 \pm 0.5$ & 0.145 \\
\hline$P$ at $9-12^{\text {th }}$ month $(\mathrm{mg} / \mathrm{dL})$ & $5.3 \pm 0.9$ & $5.9 \pm 1.1$ & 0.010 \\
\hline CaxP at $9-12^{\text {th }}$ month & $46.6 \pm 9.5$ & $53.2 \pm 11.1$ & 0.006 \\
\hline Basal ALP (U/L) & $82(66.5-112.5)$ & $97.5(65-149.5)$ & 0.288 \\
\hline ALP at $4^{\text {th }}$ month $(\mathrm{U} / \mathrm{L})$ & $98(77-125.5)$ & $99.5(77.5-164.5)$ & 0.570 \\
\hline ALP at $7^{\text {th }}$ month $(\mathrm{U} / \mathrm{L})$ & $92(74-137)$ & $101.5(81-154.5)$ & 0.189 \\
\hline ALP at $10^{\text {th }}$ month $(\mathrm{U} / \mathrm{L})$ & $132.5(96-181.5)$ & $143.5(97-232)$ & 0.465 \\
\hline Hypercalcemia frequency (months) & $0.5(0-3.5)$ & $0(0-2)$ & 0.511 \\
\hline Hyperphosphatemia frequency (months) & $4.4 \pm 3.4$ & $7.3 \pm 3.8$ & 0.001 \\
\hline Frequency of CaxP >55 (months) & $2(0-4.5)$ & $4(1-7)$ & 0.036 \\
\hline
\end{tabular}


The frequency of hyperphosphatemia and CaxP being $>55$ in 1 year were statistically lower in the paricalcitol group than in the calcitriol group ( $p<0.001$ and $p=0.036$, respectively). In addition, hypercalcemia frequency was significantly different between the groups $(p=0.511)$ (Table 2). Examination of the elemental calcium load in patients for 1 year revealed that the paricalcitol group received less calcium than the calcitriol group, but this difference only reached statistical significance between the $4^{\text {th }}$ and $6^{\text {th }}$ months $(p=0.022)$. There were no statistically significant differences between the sevelamer doses received by both the groups $(p>0.05)$. The doses of vitamin $D$ receptor activator received by the patients over 1 year were statistically significantly higher in the paricalcitol group than in the calcitriol group $(p<0.05)$. The frequency of discontinuation of vitamin $\mathrm{D}$ receptor activator treatment due to any reason was statistically significantly lower in the paricalcitol group than in the calcitriol group $(p<0.001)$ (Table 3). The mean systolic and diastolic blood pressures during hemodialysis sessions as well as the rate of angiotensin-converting enzyme inhibitor and angiotensin II receptor antagonist use was statistically similar in the groups ( $p>0.05)$.

FGF-23 levels in the paricalcitol group were significantly lower than those in the calcitriol group at 1-year $(p=0.036)$; however, Klotho and $25(\mathrm{OH})$ $D$ levels were significantly higher $(p=0.044$ and $p=0.044$ respectively)
(Table 4). FGF-23 levels had a positive correlation with mean phosphorous $(r=0.275 ; p=0.014)$ and mean CaxP $(r=0.278 ; p=0.013)$. In addition, a positive correlation was noted between $25(\mathrm{OH}) \mathrm{D}$ and the annual mean dose of vitamin D receptor activator drug $(r=0.252 ; p=0.024)$.

The PWV at the beginning of the study was statistically similar in the two groups ( $p=0.399$ ); however, at 1 year, this value was statistically significantly lower in the paricalcitol group than in the calcitriol group $(p=0.002)$ (Table 5). Considering PWV change as the dependent variable, FGF-23 level was found to be the most powerful determinant in multiple regression analysis $(p=0.004)$. When the patients were divided into two groups according to the PWV values at the beginning and end of the study, the demographic and baseline laboratory values of 45 patients with baseline PWV measurements $<7 \mathrm{~m} / \mathrm{sec}$ and 35 patients with PWV values $>7 \mathrm{~m} / \mathrm{sec}$ after 1 year were statistically similar ( $p>0.05$ for all) (Table 6). At the end of the first year, the PWV of 36 patients was $<7 \mathrm{~m} / \mathrm{s}$ and of 44 patients was $>7 \mathrm{~m} / \mathrm{s}$, with the annual PWVs being statistically similar in both these groups ( $p>0.05$ for all). At the end of the year, $63.9 \%$ of patients with PWV $<7 \mathrm{~m} / \mathrm{s}$ were receiving paricalcitol, which was statistically significantly higher than the proportion of patients receiving calcitriol (36.1\%) $(p<0.05)$ (Table 7).

Table 3. Annual phosphorus binder, vitamin D receptor activator doses, vitamin D/PTH index, and vitamin D skipping times in both groups

\begin{tabular}{|c|c|c|c|}
\hline Mean \pm SD, median (IR) & Paricalcitol group $(n=40)$ & Calcitriol group $(n=40)$ & p-value \\
\hline Elemental Ca dose of $1^{\text {st }}-3^{\text {rd }}$ months (g) & $1.8(0-6.7)$ & $5.3(0-8.8)$ & 0.120 \\
\hline Elemental Ca dose of $4-6^{\text {th }}$ months (g) & $2.3(0-7.5)$ & $6.1(1.8-11.4)$ & 0.022 \\
\hline Elemental Ca dose of $7-9^{\text {th }}$ months (g) & $5.0 \pm 5.2$ & $7.2 \pm 5.3$ & 0.079 \\
\hline Elemental Ca dose of $10-12^{\text {th }}$ months (g) & $4.7(0-8.8)$ & $7.9(2.3-12.3)$ & 0.058 \\
\hline Dose of sevelamer $1^{\text {st }}-3^{\text {rd }}$ months (g) & $8.4(0-24.3)$ & $11.2(0-23.3)$ & 0.956 \\
\hline Dose of sevelamer $4-6^{\text {th }}$ months (g) & $14(0-28)$ & $5.6(0-22.4)$ & 0.383 \\
\hline Dose of sevelamer $7-9^{\text {th }}$ months (g) & $22.4(0-33.6)$ & $22.4(0-33.6)$ & 0.933 \\
\hline Dose of sevelamer $10-12^{\text {th }}$ months (g) & $22.4(0-33.6)$ & $30.8(0-33.6)$ & 0.353 \\
\hline Dose of vitamin D equivalent $1^{\text {st }}-3^{\text {rd }}$ month ( $\mu \mathrm{g} /$ week) & $5(4.2-6.7)$ & $2(1.3-4)$ & 0.001 \\
\hline Dose of vitamin D equivalent $4-6^{\text {th }}$ month ( $\mu \mathrm{g} /$ week) & $5(3.3-7.5)$ & $2(0.7-4)$ & 0.003 \\
\hline Dose of vitamin D equivalent $7-9^{\text {th }}$ month ( $\mu \mathrm{g} /$ week) & $5(1.9-5)$ & $2(1.3-4)$ & 0.024 \\
\hline Dose of vitamin D equivalent $10-12^{\text {th }}$ month ( $\mu \mathrm{g} /$ week) & $4.2(2.3-5)$ & $2(1.7-4)$ & 0.010 \\
\hline Frequency of treatment discontinuation (month) & $0(0-3)$ & $3.5(2-5.5)$ & 0.001 \\
\hline
\end{tabular}

Table 4. Protective and accelerator markers of vascular calcification levels of both groups

\begin{tabular}{|l|l|l|l|}
\hline Mean \pm SD, median $(\mathrm{IR})$ & Paricalcitol group $(\mathbf{n}=\mathbf{4 0})$ & Calcitriol group $(\mathbf{n}=\mathbf{4 0})$ & $\mathbf{p}$-value \\
\hline FGF-23 $(\mathrm{pg} / \mathrm{mL})$ & $18.7(15.6-38.4)$ & $36.4(16.7-75.6)$ & 0.036 \\
\hline Klotho $(\mathrm{ng} / \mathrm{mL})$ & $0.9(0.3-2)$ & $0.3(0.2-1.1)$ & 0.044 \\
\hline 25-hydroxyvitamin D $(\mu \mathrm{g} / \mathrm{L})$ & $25(20-29)$ & $21(18-24.5)$ & 0.044 \\
\hline
\end{tabular}

FGF-23: Fibroblast growth factor-23, IR: interquartile range, SD: standard deviation

Table 5. Pulse wave velocity in both groups at baseline (PWV1) and the end of study (PWV2) and 1-year variation

\begin{tabular}{|l|l|l|l|}
\hline Mean \pm SD, median (IR) & Paricalcitol group $(\mathbf{n}=\mathbf{4 0})$ & Calcitriol group ( $\mathbf{n}=\mathbf{4 0 )}$ \\
\hline PWV1 (m/sec) & $7.67 \pm 3.01$ & $8.21 \pm 2.64$ \\
\hline PWV2 (m/sec) & $7.07 \pm 2.02$ & $8.97 \pm 3.26$ \\
\hline PWV variation (\%) & $-1.56 \pm 39.6$ & $+18.6 \pm 59.4$ \\
\hline
\end{tabular}

PWV: Pulse wave velocity, IR: interquartile range, SD: standard deviation 


\section{Discussion}

Secondary hyperparathyroidism caused by chronic renal failure in HPs is considered an unconventional risk factor in the development of vascular calcification and is associated with increased mortality for both predialysis patients and patients undergoing dialysis (1). In our study, baseline PTH values were similar in both the groups, but 1-year PTH values non-significantly increased by $10.3 \%$ in the paricalcitol arm and by $35 \%$ in the calcitriol arm. Accordingly, paricalcitol treatment might be considered more effective in PTH control.

Phosphorus plays a key role in the pathogenesis of vascular calcification and is associated with its prevalence and progression in HPs. In the general population, phosphorus levels in the upper limit of normal were associated with increased cardiovascular and all-cause mortality (7). In in vitro experiments, phosphorus was shown to increase vascular calcification in vascular smooth muscle cells in a dose-dependent manner (8). In our study, we observed that patients in the paricalcitol group achieved significantly better control of phosphorus for a year than patients in the calcitriol $(p<0.05)$. Similarly, there was a close relationship between high serum calcium levels and the development of vascular calcification in patients undergoing MHD (9). Especially the use of calcium-containing phosphorus binders has been shown to cause vascular calcification by inducing a positive calcium balance (10). Calcium alone can cause vascular calcification in vitro (11). In our study, basal serum calcium levels were similar in both the groups, and the tendency to develop hypercalcemia was more frequently observed in the calcitriol group, albeit non-significantly. One aspect of calciumphosphorus balance is the synergistic effect induced by calcium and phosphorus in the calcification of vascular smooth muscle cells, which is called CaxP (12). In an aortic culture model, increasing the doses of calcium and phosphorus in vascular smooth muscle cells resulted in calcification via a synergistic effect; in addition, calcium was found to be a more potent stimulant than phosphorus $(13,14)$. Similarly, in our study, CaxP value was significantly controlled during the follow-up in the paricalcitol group than in the calcitriol group $(p<0.005)$. Therefore, in the treatment of secondary hyperparathyroidism, we believe that reducing the frequency of hypercalcemia and hyperphosphatemia and maintaining within normal values should the main focus, rather than PTH suppression. In view of all these findings, it is possible that paricalcitol treatment causes hyperphosphatemia and hypercalcemia less frequently; therefore, it is superior to calcitriol in terms of treatment sustainability.

Table 6. Baseline laboratory values according to baseline PWV (PWV1)

\begin{tabular}{|c|c|c|c|}
\hline Mean \pm SD, median (IR) & PWV1 <7 m/sec $(n=37)$ & PWV1 $>7 \mathrm{~m} / \mathrm{sec}(\mathrm{n}=43)$ & p-value \\
\hline Basal PTH (pg/mL) & $558.6 \pm 148.4$ & $494.4 \pm 168.3$ & 0.074 \\
\hline Basal Ca (mg/dL) & $8.6 \pm 0.6$ & $8.5 \pm 0.4$ & 0.138 \\
\hline Basal P (mg/dL) & $5.2 \pm 0.9$ & $5.4 \pm 1.2$ & 0.563 \\
\hline Basal CaxP & $45.9 \pm 8.9$ & $44.3 \pm 9.8$ & 0.442 \\
\hline Basal ALP (U/L) & $96(73-127)$ & $78(63-123)$ & 0.065 \\
\hline Basal hemoglobin (g/dL) & $11.0 \pm 1.4$ & $10.9 \pm 1.3$ & 0.757 \\
\hline Basal albumin (g/dL) & $3.6 \pm 0.3$ & $3.6 \pm 0.3$ & 0.593 \\
\hline Basal CRP (mg/L) & $6.2(3.1-15.3)$ & $7.3(2.7-14.2)$ & 0.930 \\
\hline
\end{tabular}

ALP: Alkaline phosphatase, Ca: calcium, CaxP: calcium-phosphorus product, CRP: C-reactive protein, P: phosphorus, PTH: parathyroid hormone, IR: interquartile range, SD: standard deviation

Table 7. Patients results according to last PWV (PWV2) values (annual average laboratory values, vitamin D receptor activator usage distributions, protective and activator markers of vascular calcification levels)

\begin{tabular}{|c|c|c|c|}
\hline Mean \pm SD, median (IR) & PWV2 $<7$ m/sec $(n=36)$ & PWV2 >7 m/sec ( $n=42)$ & p-value \\
\hline PTH (pg/mL) & $592.6 \pm 224.8$ & $573.7 \pm 189.1$ & 0.685 \\
\hline $\mathrm{Ca}(\mathrm{mg} / \mathrm{dL})$ & $8.8 \pm 0.4$ & $8.7 \pm 0.4$ & 0.188 \\
\hline $\mathrm{P}(\mathrm{mg} / \mathrm{dL})$ & $5.6 \pm 0.8$ & $5.6 \pm 0.9$ & 0.934 \\
\hline $\operatorname{CaxP}\left(\mathrm{mg}^{2} / \mathrm{dL}^{2}\right)$ & $49.8 \pm 8.4$ & $49.2 \pm 9.2$ & 0.754 \\
\hline $\operatorname{ALP}(\mathrm{U} / \mathrm{L})$ & $111.1(91.6-177.1)$ & $97.1(78.3-168.5)$ & 0.095 \\
\hline Hemoglobin (g/dL) & $10.9 \pm 1.1$ & $10.9 \pm 1.1$ & 0.697 \\
\hline Albumin (g/dL) & $3.8 \pm 0.26$ & $3.7 \pm 0.25$ & 0.468 \\
\hline $\mathrm{CRP}(\mathrm{mg} / \mathrm{L})$ & $9.8(4.0-17.5)$ & $6.4(3.4-11.8)$ & 0.376 \\
\hline Ratio of patients using paricalcitol (\%) & $23(63.9)$ & $17(38.6)$ & \multirow{2}{*}{0.025} \\
\hline Ratio of patients using calcitriol (\%) & $13(36.1)$ & $27(61.4)$ & \\
\hline FGF-23 (pg/mL) & $23.8(15.6-54.6)$ & $29.2(15.6-75.6)$ & 0.816 \\
\hline Klotho (ng/mL) & $1.1(0.3-2.6)$ & $0.4(0.2-1)$ & 0.044 \\
\hline 25-hydroxyvitamin D ( $\mu \mathrm{g} / \mathrm{L})$ & $24(18-29.5)$ & $22.5(19-26)$ & 0.405 \\
\hline
\end{tabular}


Studies suggest that the main point for FGF-23 elevation in patients undergoing MHD is the presence of secondary hyperparathyroidism. PTH has been shown to increase FGF-23 expression in in vivo and in vitro environments (15). In addition, calcium itself directly increases FGF-23 mRNA levels, which consequently increases the serum FGF23 level independently from serum phosphorus and vitamin D levels (16). Klotho, which is known as the cofactor of FGF-23, is significantly reduced in HPs (17). Klotho deficiency can aggravate impaired mineral metabolism in patients undergoing MHD and increase non-renal complications (18). Reportedly, Klotho deficiency is associated with secondary hyperparathyroidism, cardiac hypertrophy, and vascular calcification and mortality $(19,20)$. In our study, consistent with that in the literature, FGF-23 levels were significantly lower and Klotho levels were significantly higher in the paricalcitol group than in the calcitriol group ( $p<0.036$ and $p<0.044$, respectively). In addition, FGF-23 levels correlated positively with mean phosphorous and mean CaxP.

In HPs, the synthesis of 1,25(OH)2D3 decreases owing to chronic kidney failure. The presence of vitamin $\mathrm{D}$ receptors in vascular smooth muscle cells may explain the role of vitamin D in vascular calcification pathogenesis (21). In HPs, decreased vitamin D has been associated with arterial stiffness (22). Lee et al. (23) showed that low vitamin 25(OH)D levels correlated with vascular calcification in both predialysis patients and in those undergoing dialysis. In addition, although the patients were receiving active vitamin $D$ treatment, a deficiency of vitamin $D$ was noted in both the groups; however, $25(\mathrm{OH}) \mathrm{D}$ levels in the paricalcitol group were significantly higher than those in the calcitriol group $(p<0.044)$. In addition, there was a positive correlation between $25(\mathrm{OH})$ $D$ levels and the average daily dose of vitamin $D(r=0.252 ; p=0.024)$.

In HPs, the two most commonly used vitamin D receptor activators are calcitriol and paricalcitol that maintain PTH within the recommended limits for the treatment of secondary hyperparathyroidism. At therapeutic doses, both drugs have hypercalcemic and hyperphosphatemic effects, but these effects are known to be less with paricalcitol than with calcitriol (24). Although vitamin D receptor activation, particularly at high doses, has been shown to cause vascular calcification, in addition to the anticalcification effects of active vitamin D therapy, drug selection may have a role in this opposite effect. Mizobuchi et al. (25) showed that calcitriol and doxercalciferol caused calcification in uremic rats, whereas similar doses of paricalcitol did not cause vascular calcification. This effect of paricalcitol has been linked to its lower hypercalcemia-inducing and hyperphosphatemia-inducing properties than those of calcitriol. A study comparing patients receiving paricalcitol and calcitriol suggested that paricalcitol offered life advantage over the later (26). All these studies revealed that vitamin $\mathrm{D}$ receptor activators had effects on vascular calcification via different mechanisms. The fact that the effects on vascular calcification are different is explained by the stimulation of the same vitamin $\mathrm{D}$ receptor with different activators, triggering different events at the cellular level.

PWV measurement the most commonly used non-invasive method for determining arterial stiffness and thus vascular calcification (27). Carotid-femoral pulse wave measurement, the method used in our study for central arterial stiffness measurement, is the gold standard
(28). In our study, PWV tended to decrease at 1 year in the paricalcitol group and tended to increase in the calcitriol group. In addition, although the initial PWV in both the groups was similar, the PWV at 1 year in the paricalcitol group was statistically significantly lower than that in the calcitriol group ( $p=0.002)$. The absence of an annual increase in PWV in the paricalcitol group may be attributed to the sustainability of treatment and less frequent observation of hyperphosphatemia and CaxP increase in this group, as well as higher levels of calcification inhibitors. Likewise, the fact that FGF-23 level was an independent variable of annual PWV change in our study, and that this value was lower than the calcitriol group, suggests that paricalcitol has positive effects on PWV change.

\section{Study Limitations}

As a limitation of our study, the number of patients enrolled was slightly low; however, this type of follow-up study, finding eligible patients is difficult. In addition, the findings could have been more informative if FGF-23 and Klotho levels were also studied at the beginning of the study.

\section{Conclusion}

We believe that paricalcitol use in HPs has greater protective effects against vascular calcification than calcitriol use owing to its positive effects on both the PTH and calcium-phosphorus balance as well as calcification markers. Therefore, we believe that paricalcitol should be the first choice for the treatment of secondary hyperparathyroidism.

Ethics Committee Approval: This study was approved by the Bașkent University Faculty of Medicine Ethical Committee (approval number: KA12/83, date: 12.05.2012)

Informed Consent: Written informed consent was obtained from all participants.

Peer-review: Externally and internally peer-reviewed.

Authorship Contributions: Concept - Z.B.; Design - S.K., Z.B., S.S.; Data Collection or Processing - Z.B.; Analysis or Interpretation - S.K., Z.B., S.S.; Literature Search - S.K., Z.B.; Writing - S.K., Z.B.

Conflict of Interest: No conflict of interest was declared by the authors.

Financial Disclosure: The authors declared that this study received no financial support.

\section{References}

1. Goodman WG, Goldin J, Kuizon BD, Yoon C, Gales B, Sider D, et al. Coronaryartery calcification in young adults with end-stage renal disease who are undergoing dialysis. N Engl J Med 2000; 342: 1478-83.

2. Desjardins L, Liabeuf S, Renard C, Lenglet A, Lemke HD, Choukroun G, et al. European Uremic Toxin (EUTox) Work Group. FGF23 is independently associated with vascular calcification but not bone mineral density in patients at various CKD stages. Osteoporos Int 2012; 23: 2017-25.

3. Hu MC, Shi M, Zhang J, Quiñones H, Griffith C, Kuro-o M, et al. Klotho deficiency causes vascular calcification in chronic kidney disease. J Am Soc Nephrol 2011; 22: 124-36.

4. Veerasamy M, Ford GA, Neely D, Bagnall A, MacGowan G, Das R, et al. Association of aging, arterial stiffness, and cardiovascular disease: a review. Cardiol Rev 2014; 22: 223-32. 
5. Covic A, Gusbeth-Tatomir P, Goldsmith DJ. Arterial stiffness in renal patients: an update. Am J Kidney Dis 2005; 45: 965-77.

6. Kelly RP, Millasseau SC, Ritter JM, Chowienczyk PJ. Vasoactive drugs influence aortic augmentation index independently of pulse-wave velocity in healthy men. Hypertension 2001; 37: 1429-33.

7. Tonelli M, Sacks F, Pfeffer M, Gao Z, Curhan G; Cholesterol and Recurrent Events Trial Investigators. Relation between serum phosphate level and cardiovascular event rate in people with coronary disease. Circulation 2005; 112: $2627-33$

8. Jono S, McKee MD, Murry CE, Shioi A, Nishizawa Y, Mori K. Phosphate regulation of vascular smooth muscle cell calcification. Circ Res 2000; 87: E10-7.

9. Block GA, Hulbert-Shearon TE, Levin NW, Port FK. Association of serum phosphorus and calcium $\mathrm{x}$ phosphate product with mortality risk in chronic hemodialysis patients: a national study. Am J Kidney Dis 1998; 31: 607-17.

10. Moe SM, Chertow GM. The case against calcium-based phosphate binders. Clin J Am Soc Nephrol 2006; 1: 697-703.

11. Yang H, Curinga G, Giachelli CM. Elevated extracellular calcium levels induce smooth muscle cell matrix mineralization in vitro. Kidney Int 2004; 66: 2293-

12. Reynolds JL, Joannides AJ, Skepper JN, McNair R, Schurgers LJ, Proudfoot $D$, et al. Human vascular smooth muscle cells undergo vesicle-mediated calcification in response to changes in extracellular calcium and phosphate concentrations: a potential mechanism for accelerated vascular calcification in ESRD. J Am Soc Nephrol 2004; 15: 2857-67.

13. Lomashvili KA, Cobbs S, Hennigar RA, Hardcastle KI, O’Neill WC. Phosphateinduced vascular calcification: role of pyrophosphate and osteopontin. J Am Soc Nephrol 2004; 15: 1392-401

14. Shroff RC, McNair R, Skepper JN, Figg N, Schurgers LJ, Deanfield J, et al. Chronic mineral dysregulation promotes vascular smooth muscle cell adaptation and extracellular matrix calcification. J Am Soc Nephrol 2010; 21: 103-12.

15. Rhee Y, Bivi N, Farrow E, Lezcano V, Plotkin LI, White KE, et al. Parathyroid hormone receptor signaling in osteocytes increases the expression of fibroblast growth factor-23 in vitro and in vivo. Bone 2011; 49: 636-43.

16. Shimada T, Yamazaki Y, Takahashi M, Hasegawa H, Urakawa I, Oshima T, et al. Vitamin D receptor-independent FGF23 actions in regulating phosphate and vitamin D metabolism. Am J Physiol Renal Physiol 2005; 289: F1088-95.
17. Koh N, Fujimori T, Nishiguchi S, Tamori A, Shiomi S, Nakatani T, et al. Severely reduced production of klotho in human chronic renal failure kidney. Biochem Biophys Res Commun 2001; 280: 1015-20.

18. Goldsmith DJ, Cunningham J. Mineral metabolism and vitamin D in chronic kidney disease--more questions than answers. Nat Rev Nephrol 2011; 7: 341-6.

19. Krajisnik T, Olauson H, Mirza MA, Hellman P, Akerström G, Westin G, et al. Parathyroid Klotho and FGF-receptor 1 expression decline with renal function in hyperparathyroid patients with chronic kidney disease and kidney transplant recipients. Kidney Int 2010; 78: 1024-32.

20. Faul C, Amaral AP, Oskouei B, Hu MC, Sloan A, Isakova T, et al. FGF23 induces left ventricular hypertrophy. J Clin Invest 2011; 121: 4393-408.

21. Andress DL. Vitamin D in chronic kidney disease: a systemic role for selective vitamin D receptor activation. Kidney Int 2006; 69: 33-43.

22. London GM, Guérin AP, Verbeke FH, Pannier B, Boutouyrie P, Marchais SJ, et al. Mineral metabolism and arterial functions in end-stage renal disease: potential role of 25-hydroxyvitamin D deficiency. J Am Soc Nephrol 2007; 18 . 613-20.

23. Lee SY, Kim HY, Gu SW, Kim HJ, Yang DH. 25-hydroxyvitamin D levels and vascular calcification in predialysis and dialysis patients with chronic kidney disease. Kidney Blood Press Res 2012; 35: 349-54.

24. Sprague SM, Llach F, Amdahl M, Taccetta C, Batlle D. Paricalcitol versus calcitriol in the treatment of secondary hyperparathyroidism. Kidney Int 2003; 63: 1483-90.

25. Mizobuchi M, Finch JL, Martin DR, Slatopolsky E. Differential effects of vitamin $D$ receptor activators on vascular calcification in uremic rats. Kidney Int 2007 72: 709-15.

26. Teng M, Wolf M, Lowrie E, Ofsthun N, Lazarus JM, Thadhani R. Survival of patients undergoing hemodialysis with paricalcitol or calcitriol therapy. $\mathrm{N}$ Engl J Med 2003; 349: 446-56.

27. Lee HY, Oh BH. Aging and arterial stiffness. Circ J 2010; 74: 2257-62.

28. Meaume S, Benetos A, Henry OF, Rudnichi A, Safar ME. Aortic pulse wave velocity predicts cardiovascular mortality in subjects $>70$ years of age. Arterioscler Thromb Vasc Biol 2001; 21: 2046-50. 